\title{
Kollégium török diákok számára
}

MIKLÓS GÁBOR - Value4Real Kft. - gabor.miklos.92@gmail.com

Érkezett: 2019. 08. 04. - Received: 04. 08. 2019. - https://doi.org/10.14382/epitoanyag-jsbcm.2019.29

\begin{abstract}
Located on the steepest street of Budapest, Student hostel for Turkish students creates a unique accommodation for those who study in the capital city of Hungary for 1 or 2 semesters. As a young architect, I wish, more and more students can have the opportunity to explore foreign countries, because these experiences can broaden their horizon. The designing area is one of the most famous historical places in Budapest, which has a romantic, mysterious atmosphere. Despite of that, Gül Baba street has a hole in the line of the historical houses, which could be closed by the designed building.

The designing process shaped to achieve two aims: connection to the atmosphere of the historical site and utilize the ancient Islamic architecture's toolbar. The first goal appears in the claddings and shape of the building mass. Ceramic surfaces can easily fit with the historical street and the environment of Gül Baba's octagonal tomb. The central organized floor plans and the interior patterns relates to the impression of the Islamic architecture.

Keywords: architecture, historical site, historic preservation, Gül Baba's octagonal tomb, ceramic cladding, Islamic architecture, architectural heritage, college, student hostel, Hungary-Turkey relations

Kulcsszavak: építészet, múemlékvédelem, múemléki környezet, Gül Baba türbéje, Gül Baba utca, kerámia burkolat, iszlám építészet, építészeti hagyományok, kollégium, diákszálló, török-magyar kapcsolatok
\end{abstract}

\section{Koncepció}

A Gül Baba türbéje és környezete egy különleges helyszín Budapest nagyvárosi forgatagában. A környék utcácskáiban sétálva az ember egy sokkal zártabb, rejtélyesebb, historikusabb világban találja magát, mint akár a pesti, akár a budai belváros nagy részében. Sajnos itt is találhatóak olyan hiányzó épülettömegek, amelyek csökkentik az arra járók teljességérzetét. Számomra a tervezési helyszín a foghijtelek beépítésével és a lejtős tereppel együtt egy komplex müszaki kihívásokat igénylő feladatot is jelentett. A helyhez társított szállásfunkcióval a nemzetközi kapcsolatok erősítését, valamint a külföldi tanulók elhelyezésének segítését kívánnám elérni. Fontosnak tartom, hogy az ember már fiatalként megismerjen új kultúrákat, bővítse a látóterét, tanuljon vagy dolgozzon külföldön.

\section{Elhelyezkedés}

A tervezett épület Budapesten, Rózsadombon, a Gül Baba utcában két üresen álló foghíj telekre épül. Az utca Budapest legmeredekebb utcájaként ismert, közvetlen környezetében található Gül Baba türbéje, ami a 20-22. számú telkekkel is szomszédos. A türbe nemcsak hazai szinten fontos mủemlék, hanem a világ legészakibb fekvésű iszlám zarándokhelye. Emiatt és az utca különleges hangulatának megőrzése érdekében a helyszín műemléki környezet alá tartozik.

\subsection{Gül Baba türbéje}

Gül Baba török dervis (szerzetes) volt, aki feltételezhetően Buda ostrománál szenvedett halálos sérülést. Nevét sokan Rózsa apóként fordítják magyarra, ami valószínúleg a rózsák iránti szeretetéből ered, ugyanis pontos neve sem tisztázott. Annyi azonban bizonyos, hogy köztiszteletnek örvendő sze- mély volt, akinek koporsóját állítólag a szultán személyesen kísérte gyászmenetén, majd e koporsó felé türbét emeltetett.A történelem aztán sok nyomot hagyott az épületen és környezetében, de még így is fenn tudott maradni az eredetihez közeli állapotában.

A türbe a török-magyar kapcsolatok XX. és XXI. századi jó viszonyát is szimbolizálja, ugyanis a 2018-ban lezáruló rekonstrukciót a két nemzet közös anyagi támogatásából valósították meg. Hazai támogatásból újult meg a türbe környezete, így a Gül Baba utca is, ami új burkolatot kapott, kedvezve így a vízelvezetésnek és csúszásmentességnek.

\subsection{Gül Baba utca}

A meredek Gül Baba utca Budapest talán leghangulatosabb utcája. A szűk kis utcából a házak lépcsősen egymásra tapadva emelkednek, amelyekből sok még eredeti, XIX. századi állapotában maradt fent. A macskaköves burkolat szintén az utca jellegzetessége.

Az utca meredekség szempontjából három szakaszból áll, a két vége lankásabb míg a középső része a legmeredekebb, ahol az tervezési terület is található. Az utca egy forgalom elől elzárt terület, behajtás csak engedéllyel lehetséges. Még hulladék elszállítás sincs az utcában.

\subsection{Telek}

A 20-22 szám alatt álló telkek a zártsorú beépítés foghíjai és egyben az utcaképet is jelentősen szegényítik. A Türbe rekonstrukciójával még nagyobb igény nyilik a két telek beépítésére, mivel az északi lépcső szomszédos vele, amely a látogatók egyik gyakori útvonala is lesz. Jelenleg a telket építési törmelék borítja, illetve az egykori házakból faltest maradványok támaszkodnak a szomszédos épületre. Ezen kívül az egykori Wagner villa 
támfalaiból is találhatóak maradványok a kertben, amelyhez egy zsalukő fal támaszkodik. Ezek állapota igencsak megromlott, müemléki értékük nincs.

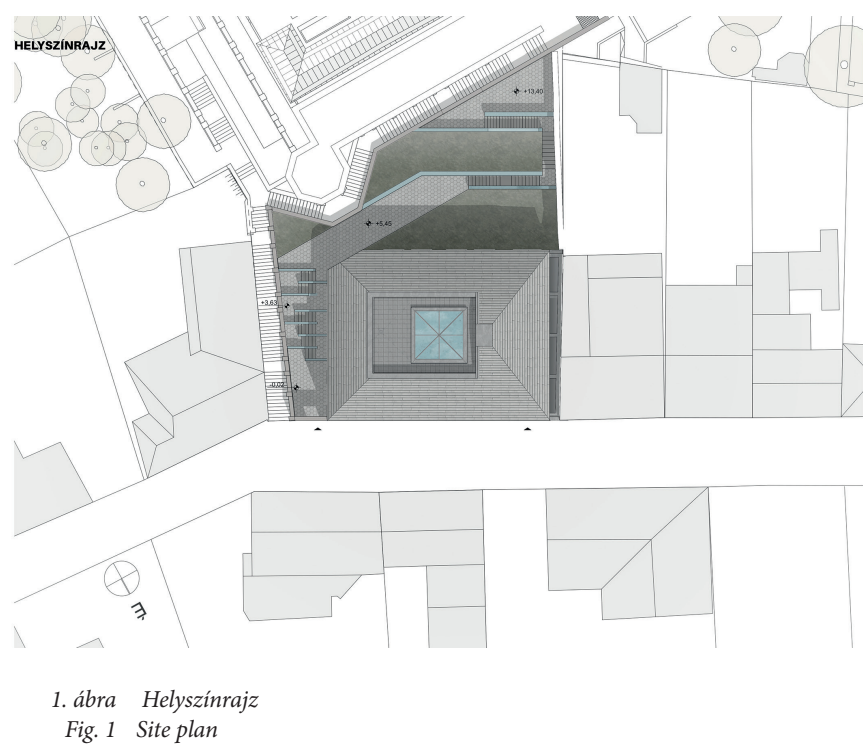

A telkek lakóövezetben, zártsorú beépítésben helyezkednek el. Maximális beépíthetőségük 65\%, amit az építési vonal még inkább leszabályoz.

\subsection{Környezeti adottságok}

\subsubsection{Talaj}

A Rózsadomb Duna-felé eső lejtőjét eocén korú ún. „budai” márga építi fel, erre alapozták például Gül Baba sírját is Az utca egy régi vízmosás nyomvonalában halad, ezért a márgát fedő agyagösszlet vastagsága változó. Sem talaj, sem rétegvíz nem várható a terület nagyobb részén, ahol a márga felszín közelbe emelkedik és felette csak sárga mállás agyagból álló takaró van.

\subsubsection{Zajhatás}

A telek zárt sorú beépítésben, sarok telekként egy kétemelet plusz tetőtér beépítéses ház és az türbéből vezető északi lépcső között helyezkedik. Az utca nagyon alacsony forgalmú zsákutca, ahol leginkább az idelátogató turisták és helyi lakosok közlekednek gyalogosan. Ez feltételezhetően a jövőben se fog változni, így alacsony zajhatásnak kitett az tervezett épület.

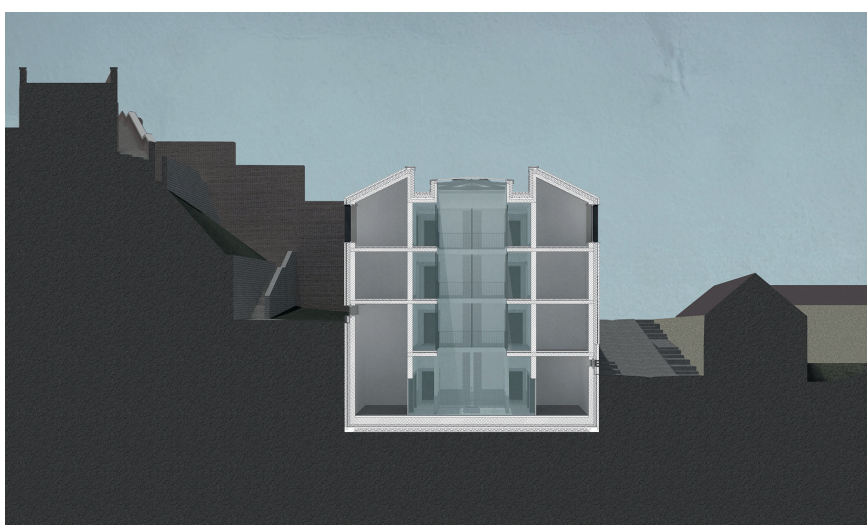

2. ábra Keresztmetszet

Fig. 2 Cross section drawing

\section{Rendeltetés}

A Gül Baba utca 20-22. szám alatti telkek lakó övezet alá tartoznak. A tervezett épület funkciója ehhez illeszkedően egy olyan kollégium, amely hosszútávú itt tanulásra fogad török ösztöndíjas diákokat. A létesítményt olyan tanulók fogják igénybe venni, akik egy nemzetközi szervezet által összeállított szállást és ösztöndíjat tartalmazó programban vesznek részt. Az intézmény célja továbbá a török-magyar kapcsolatok erősítése.

\subsection{Török-magyar kapcsolatok}

A XIX. század második felétől kezdett a történelem miatti ellenséges hangulat megváltozni a két nemzet között, föleg az értelmiségi rétegben. A századfordulón előbb Konstantinápolyban alapult Magyar Intézet, majd itthon Magyar Turáni társaság. Ezeknek és a klebelsbergi kultúrpolitikának hála például az, hogy Kós Károly ösztöndíjasként tanulmányozhatta Isztanbult és oszmán hallgatók érkeztek Budapestre.

\subsection{Funkció, lehetséges megrendelő}

A török-magyar kulturális kapcsolat erősítésének fontos része a fiataloknak megteremteni a lehetőséget a másik ország, másik kultúra megismerésére, illetve a közös szellemi értékek megtalálására. Ehhez nyújt lehetőséget például egy itthon is működő nemzetközi cég, amely török diákoknak biztosít külföldi tanulmányi csomagokat. Ezek a csomagok nem csak az ösztöndíjat, hanem a szálláslehetőséget is tartalmazzák, így gyorsítva az ügyintézést.

\section{4. Építészeti koncepció}

A tervezést két nagyobb cél határozta meg: a hely történeti atmoszférájára való kapcsolódás és az iszlám építészetből hozott építészeti eszköztár felhasználása. Előbbi főleg külső anyaghasználatban és a tömeg alakításban jelenik meg.

A szállásépület egy zárt belső udvar köré szerveződik, ami a legalsó szinten egy külső udvarból, recepción keresztül nyílik meg. Ezen a szinten kap helyet egy előadóterem, egy imaszoba valamint gépészeti és kiszolgáló funkciók. A felette lévő szint a meredek utca és telek viszonyai miatt még részben föld alatt van, illetve egy gazdasági bejárattal is rendelkezik. Ezenkívül itt kapnak helyett a közös használatú terek, illetve két lakószoba is. A felette lévő két szinten 8-8 lakószoba kerül kialakításra, amelyből a legfelsőbb szintiek tetőtériek. Az épület tetejét egy a kontúrtól elhúzott lapos tető fedi, amelyhez oldalanként magas tető zár fel, így kialakítva egy teknőben lévő tetőtéri helyet, ahonnan feltárul a budai hegyoldal panorámája.

\subsection{Alaprajzi rendszer}

Már a tervezés kezdeti fázisaitól az épület meghatározó elemét képezte az udvar, mint szervező erő használata. Az eszköz részben a környék beépítései miatt (hosszú udvaros házak), részben az iszlám építészeti vonatkozása miatt vált a terv központi részévé. A tervezett beépítés megkülönböztetett udvarok kapcsolatából jön létre. 

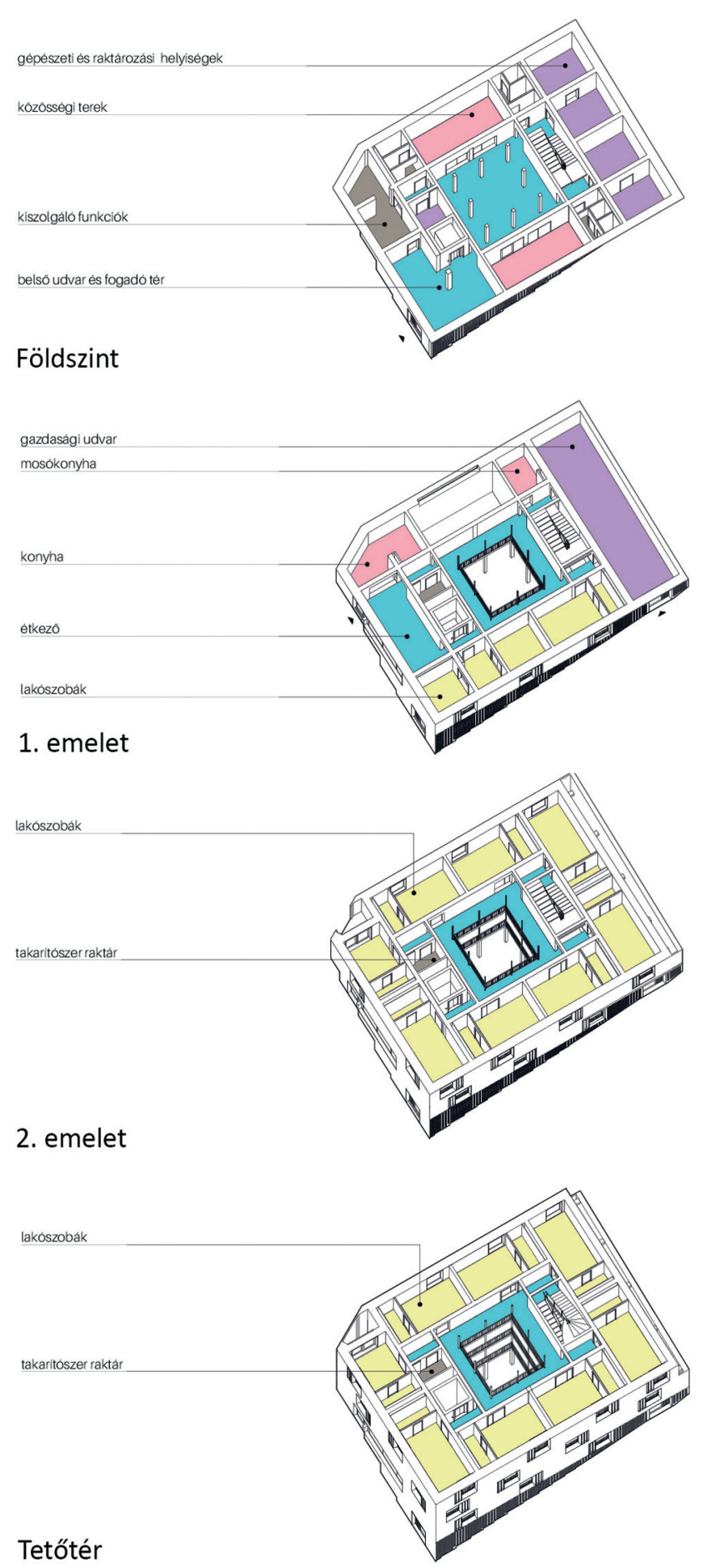

3. ábra Alaprajzi elrendezések

Fig. 3 Floor plans

Az épület fö szervező magja egy négyzet alaprajzú folyosókkal határolt, fedett belső udvar. Az iszlám építészet talán legfőbb jellemzői a szerkesztettség és a geometria. Az iszlám belső udvar köré meghatározott funkciójú terek kapcsolódtak. Érdekesség, hogy a centrális belső udvar sokszor nem középről, hanem valamelyik sarokból tárul fel. Ezen belső terek közepén sok helyen kút vagy kisebb medence áll, amely körül növényzet vagy ülö alkalmatosságok is helyet kaptak. A vízfelület jelenléte

az esztétika mellett klimatikus szempontból is hasznos volt a Közel-Keleten ugyanis párolgás útján hütötte a körülötte lévő tereket. Emellett az iszlám vallásban kulcsfontosságú szerepe van a megtisztulásnak, így például az imádkozást is megmosakodással kezdik.

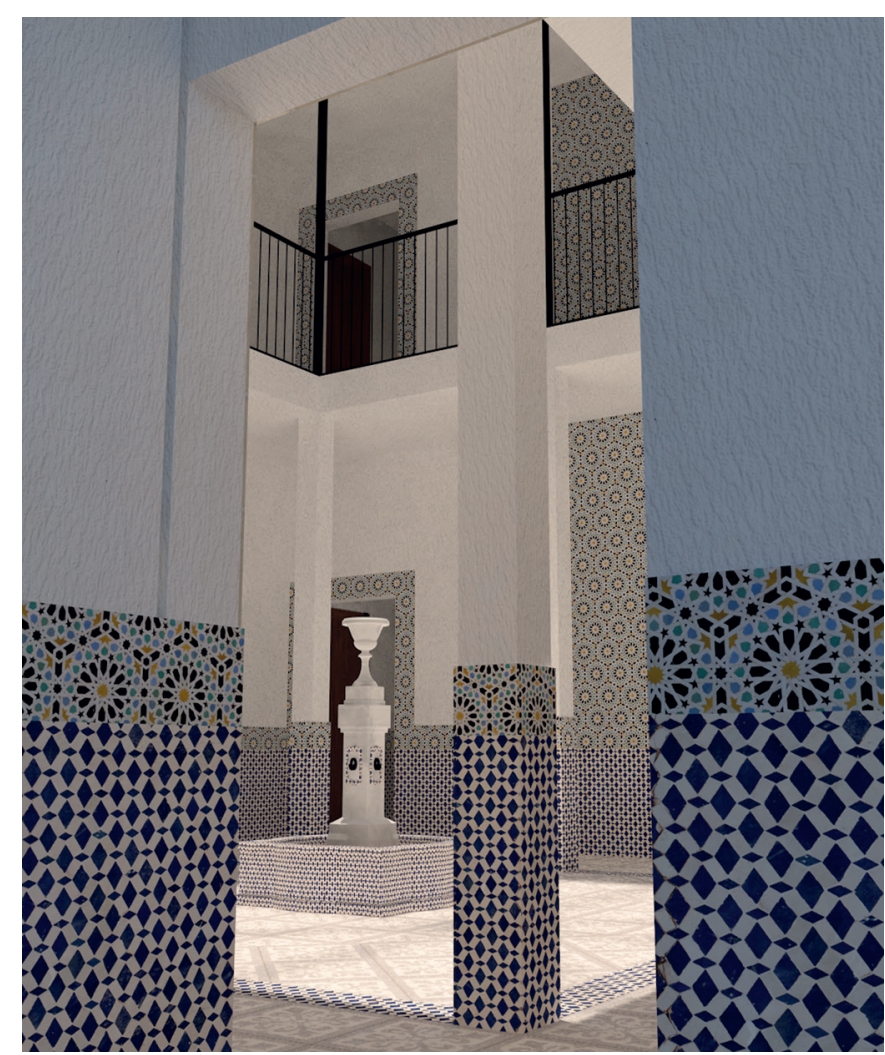

4. ábra Belső látványterv - udvar

Fig. 4 Interior visualization - courtyard

A kút elhelyezésének helyi jelentés tartalma is van, ugyanis a Gül Baba utca 26. szám alatt lakott Toroczkai Wigand Ede építész, iparművész, író, akinek saját kertjében is rózsák körülvett kút állott. A Magyarság folyóiratban így értekezett a harmonikus otthon megteremtéséről:

„Ha lehet, kertre forditsuk a dolgozószobát. Ha a viszonyok engedik, rózsás vagy medencés udvarra tekintsen, hol a víz csobogása jelezze a csendes, de örökké lüktetô életet." [1]

\subsubsection{Bejárati udvar}

A belső udvarhoz szervesen kapcsolódik a fogadótér, valamint a bejárati külső udvar. Az utca zártsorú egymáshoz tapadó épületfalai föleg az utca felső illetve az alsó szakaszán jellemzőek, azonban a középső szakaszon elvétve találunk példákat udvarból való megnyitásra is. Ez a megérkezés egyfelől szeretné a titokzatosságával hívogatni a látogatót, hasonlóan akár egy mediterrán szük utcás városka sikátoraihoz. Emellett az, hogy az épülettömeg nem ér ki a lépcsőig, így az utcáról fellátni egészen a Wagner-villa rekonstruált bástyáig. Ebbe az udvarba érkezve egy titokzatos lépcsőt láthatunk, amely felvezet a hátsó kertbe, valamint az első szinti közösségi terek szintjére is bejutást enged. A lépcső szerkesztése geometrikus indíttatású volt, azzal a céllal, hogy a bejárati kapuból egy mintaként jelenjen meg. 


\subsubsection{Hátsó kert}

A hátsó kert teraszosan lépcsőzik fel a meredek domboldalra, hasonlóan felső szomszédok kertjéhez. Az utca felső szakaszán a telekkel megegyező oldalon ugyanis a legtöbb teleknek két utca kapcsolata is adódik a hátsó kertek fellépcsőzése miatt, így például a gépkocsi tárolást is könnyen meg tudják oldani a Turbán utca felöl. A 22. számú telek azonban nem ér fel teljesen a Turbán utcáig, így innen nem közelíthető meg a ház. Azonban a hátsó kert egy nyugodt, pihenésre alkalmas helyet teremt, ahová fel tudnak sétálni a bentlakók. A kert teraszain a hely történetéhez hűen rózsákat ültethetnek.

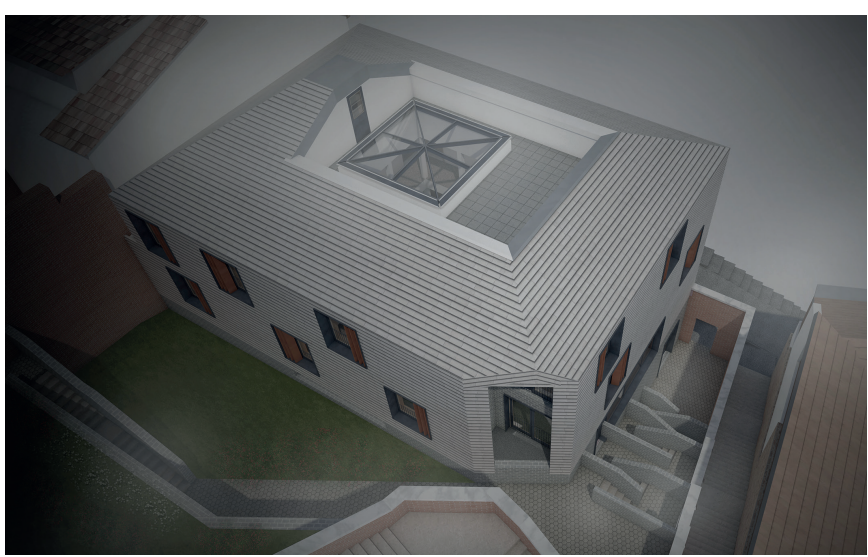

5. ábra Külső látványterv - hátsó kert

Fig. 5 Exterior visualization-backyard

\subsubsection{Gazdasági udvar}

Mivel az utca forgalomtól elzárt terület így a gépkocsival való megközelítés is csak engedéllyel lehetséges, emiatt az ilyen típusú forgalom nem gyakori. A tervezés korábbi fázisaiban a szomszédházhoz tapadó első emeleti udvar még gépkocsi bejáróval rendelkezett, azonban a helyi lakókkal való beszélgetés alapján megtudtam, hogy az utca ezen szakaszán a szabályos garázs kialakítása szinte lehetetlen. Így a végső döntés egy széles kapu és a mögötte található hosszúkás gazdasági udvar mellett történt, de igény esetén a garázskapu beépítésére is lenne lehetőség. Az áruszállítást az utcában megálló furgonból kipakolva tudják végezni az ottdolgozók. A belső térben rámpán keresztül lehet lejutni az 1. emelet szintjére, ahonnan lépcsőn azonnal le tudunk jutni a földszinti kiszolgáló és gépészeti helyiségekbe.

\subsection{Tömegformálás}

A hely adottságai miatt a tömegformálás kulcsfontosságú kérdés volt a tervezés kezdeti fázisaitól. Az utca, valamint a telek meredek emelkedése miatt a terepbe illesztés és a homlokzat lépcsőztetése sok próbálkozás árán nyerte el a tervezett formáját. A Gül Baba utcába tervezett épület a Türbéből lejövő nagyméretű tégla korlátot folytatva alakít ki egy alsó szinti foglalatot, amelyre egy egységes megjelenésű tömeg ül rá. A téglalap alaprajzú tömeg a Wagner-villa bástyájához közeli sarkon letörik, ezzel mintegy reagál a bástya által kialakított kitüremkedésre és teret ad a hátsó kertbe való átközlekedésre. Az utcafronton a gazdasági udvar felett egy légakna került kialakításra, ami által az épület kissé elhúzódik a szomszédjától ezzel is erősítve az épület befelé forduló, centrális jellegét. A telek további az utca többi házához képest ritka adottsága, hogy gyakorlatilag saroktelekként az utcából két homlokzata is megmutatkozik. A félnyeregtetőként felzáró magastetők alkalmazását azért tartottam fontosnak, hogy a ház ekképpen is illeszkedjen az utcaképbe, viszont lehetőség adódjon egy olyan tetőterasz kialakítására, ami az utcából nem látszódik.

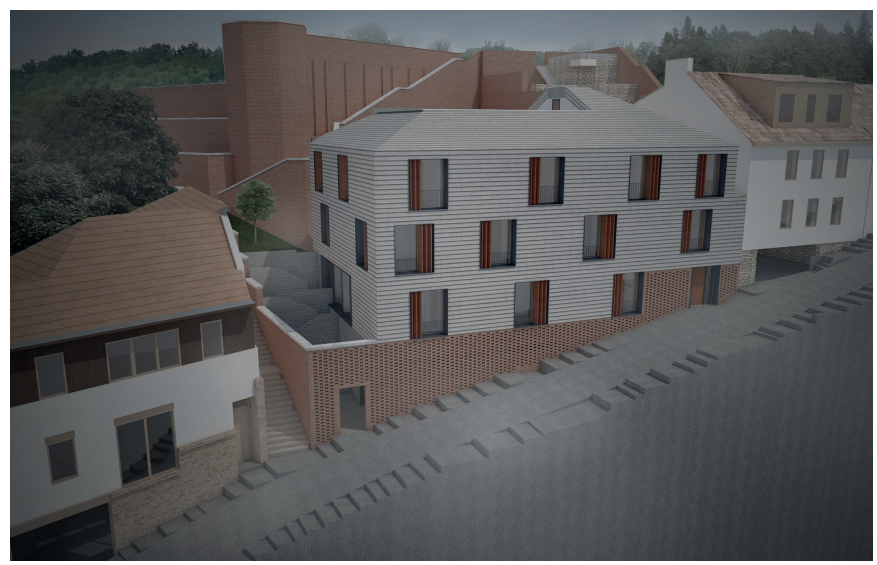

6. ábra Külsö látványterv - utcai tömeg

Fig. 6 Exterior visualization - streetview

\subsection{Anyaghasználat}

Az épület anyaghasználatában a környezetében lévő Türbéhez valamint az utca többi épületén is fellelhetö anyaghoz kíván igazodni. Így került a választás a kerámia anyagok széleskörü alkalmazására.
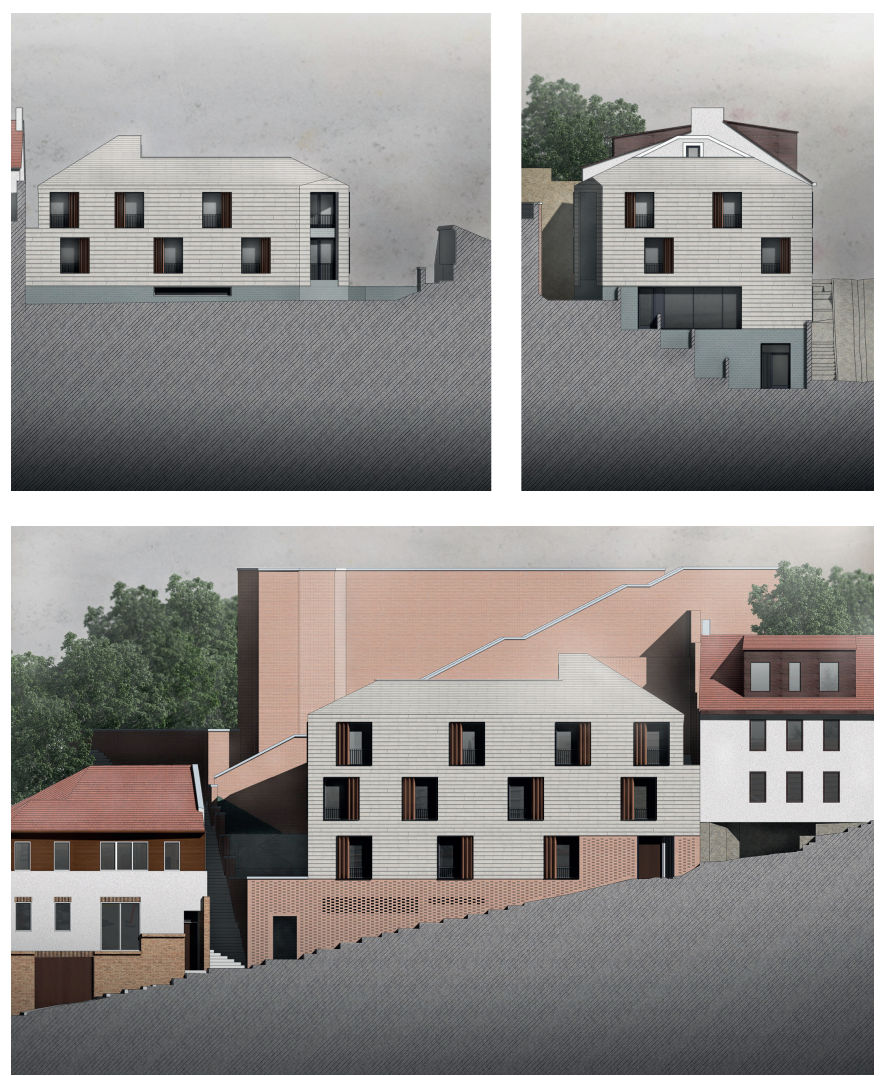

7. ábra Homlokzatok

Fig. 7 Elevations 


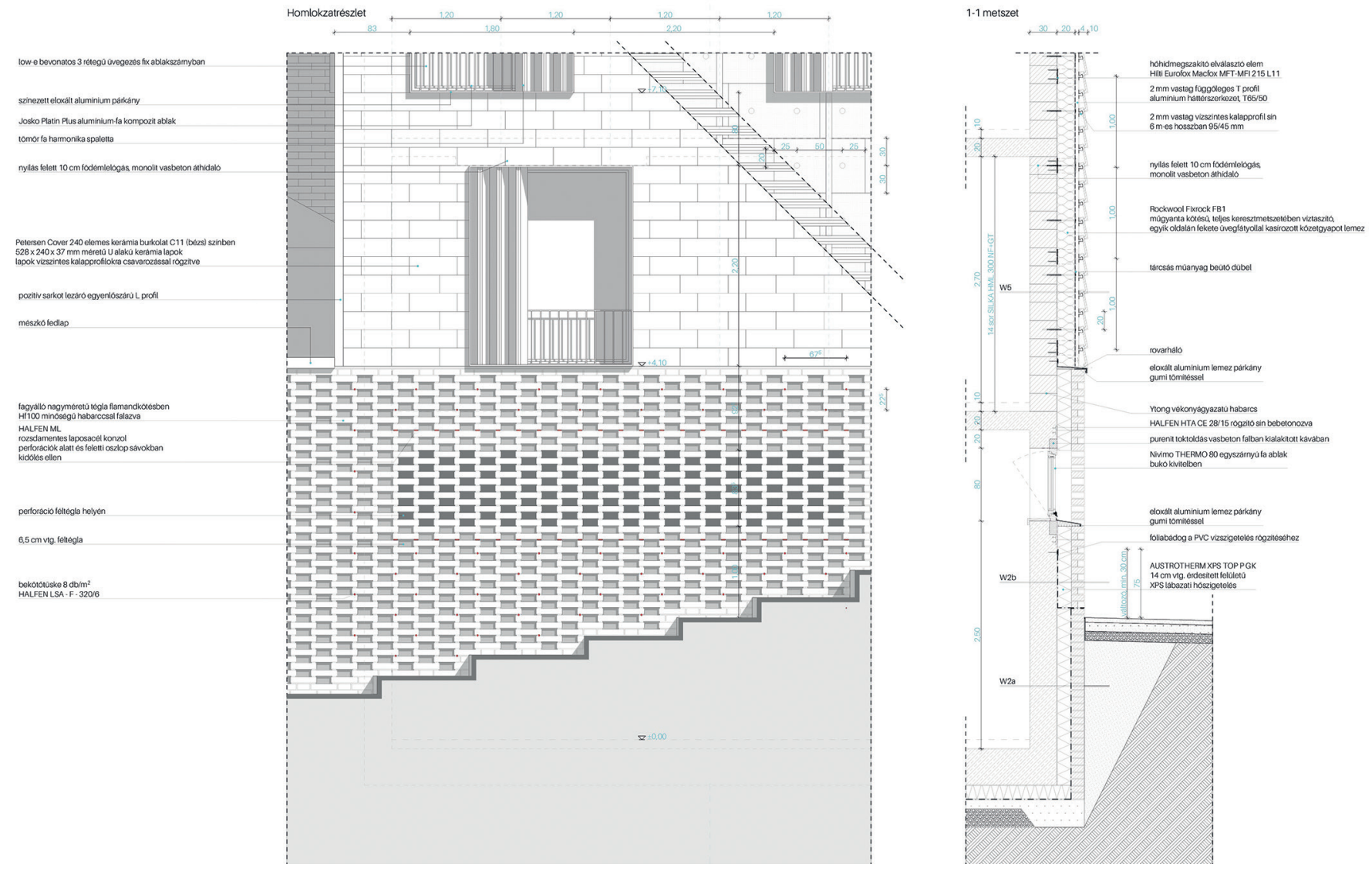

8. ábra Homlokzati részlet

Fig. 8 Elevation detail

\subsubsection{Utcai homlokzat}

A fentebb említett Türbéből lejövő korlát nagyméretű téglából készült, ami a házon egy perforált mintában folytatódik ugyanazon anyaggal és kötésrenddel. Az erre ráülő tömeg egységes megjelenését a Petersen Cover nevü, dán nagy elemes kerámiaburkolat biztosítja, amit fal- és tetőburkolatként is alkalmazható. Rögzítése vízszintes alumínium kalapprofilokra csavarozással történik, amik függőleges T profilú vázhoz kapcsolódnak. Ezek a bordák pontszerüen vannak a szerkezethez felfogatva hőhídmentes távtartókkal.

\subsubsection{Belső udvar}

A belső udvarban az iszlám építészetet idéző mázas kerámiaburkolatok jelennek meg. E minták megidézése a mai csempeburkolatokon igen népszerü. A burkolatok poziciójuk szerint megkülönböztettek: így van türkíz lábazati, nagyelemes padló- és kiemelt szalag, illetve „terülo’” burkolat. Ezek a burkolatok kifutnak a belső udvarból a fogadótérbe valamint a tetőteraszra is.

\subsubsection{Kerti homlokzat}

A belső tér világa a tetőn kívül a kerti homlokzatok mázas kerámia lábazatán is visszaköszön. A kerti homlokzatok emellett nagyobb megnyitásokkal teremtenek kapcsolatot a külső és belső tér között.

\section{5. Összefoglalás}

Műemlékeink és műemléki környezeteink védelme elsődleges szempont kellene legyen a hazai építész kultúrában. Tervemmel szeretném rávilágítani a figyelmet arra, hogy mennyire fontos egy ilyen különleges helyszínen a múlthoz való kapcsolódás és a modern építészeti eszközök összhangba hozása. Ez a kis szállásépület kapcsolatokat keres tömegében a környezetével, funkciójában a kultúrákkal.

\section{Köszönetnyilvánítás}

Köszönet illeti Nagy Mártont, aki diplomamunkám és több egyetemi tervezési tárgyam során építész konzulensként adta át nekem szakmai tudását.

\section{Hivatkozások}

[1] Thoroczkai Wigand Ede: „Hogyan öntsünk lelket otthonunkba. Az ízléses lakás problémája." - Magyarság, 1923

Ref.:

Miklós, Gábor: Kollégium török diákok számára Építőanyag - Journal of Silicate Based and Composite Materials, Vol. 71, No. 5 (2019), 168-172. p. https://doi.org/10.14382/epitoanyag-jsbcm.2019.29 